Jurnal Riset Agama

Volume 1, Nomor 2 (Agustus 2021): 323-337

DOI: $10.15575 /$ jra.v1i2.14570

https://journal.uinsgd.ac.id/index.php/jra

\title{
Solusi Pengolahan Sampah dalam Problem Pencemaran Bumi untuk Kebersihan Lingkungan Hidup: Studi Syarah Hadis
}

\author{
Muhammad Daffa \\ Jurusan Ilmu Hadis, Fakultas Ushuluddin, \\ UIN Sunan Gunung Djati Bandung \\ mdmdaffa12@gmail.com
}

\begin{abstract}
The purpose of this study is to discuss the hadith about cleanliness associated with waste management. This research method applies a qualitative type through library research and field studies using content analysis. The discussion of this research includes general views of cleanliness, hadith about cleanliness, and creating environmental cleanliness through waste management. This study concludes that cleanliness is the main thing in Islam as a half faith that can be done through waste management in order to create the expected environment. Waste management can be done by reducing, reusing, and recycling. The solution to overcome plastic waste is carried out through education, action, and campaigns.
\end{abstract}

Keywords: Cleanliness; Hadith; Management; Rubbish; Syarah.

\begin{abstract}
Abstrak
Tujuan penelitian ini adalah membahas hadis tentang kebersihan dikaitkan dengan pengelolaan sampah. Metode penelitian ini menerapkan jenis kualitatif melalui studi pustaka dan studi lapangan dengan menggunakan analisis isi. Pembahasan penelitian ini meliputi pandangan umum kebersihan, hadis tentang kebersihan, dan menciptakan kebersihan lingkungan melalui pengelolaan sampah. Penelitian ini menyimpulkan bahwa kebersihan merupakan hal utama dalam Islam sebagai setengah iman yang dapat dilakukan melalui pengelolaan sampah dalam rangka menciptakan lingkungan yang diharapkan. Pengelolaan sampah dapat dilakukan dengan mengurangi, menggunakan kembali, dan mendaur ulang. Adapun solusi mengatasi sampah plastik dilakukan dengan edukasi, aksi, dan kampanye.
\end{abstract}

Kata kunci: Hadis; Kebersihan; Pengelolaan; Sampah; Syarah. 
Jurnal Riset Agama, Volume 1, Nomor 2 (Agustus 2021): 323-337

Muhammad Daffa/Solusi Pengolahan Sampah dalam Problem Pencemaran

Bumi untuk Kebersihan Lingkungan Hidup: Studi Syarah Hadis

\section{Pendahuluan}

Sampah bertambah seiring dengan semakin banyak kebutuhan manusia. Kegiatan konsumsi membuat sampah menjadi masalah dalam kehidupan. Namun, adanya hadis tentang kebersihan serta pengelolaan sampah dengan baik telah diajarkan dalam kehidupan masyarakat. Oleh karena itu, pengkajian hadis tentang kebersihan akan bersinergi dengan pengelolaan sampah di lingkungan masyarakat.

Sejumlah pakar telah melakukan penelitian berkenaan dengan kebersihan sebagaimana dalam tinjauan pustaka penelitian ini. Antara lain Kahfi, Ashabul (2017), Judul “Tinjauan terhadap Pengelolaan Sampah," Penerbit Jurisprudentie UIN Alauddin Makassar. Penelitian ini membahas tentang permasalahan lingkungan hidup yang dihadapi oleh masyarakat. Pertumbuhan penduduk, kesediaan lahan dan sumber daya energi memiliki dampak yang signifikan terhadap lingkungan. Faktor terpenting dalam permasalahan ini adalah besarnya populasi manusia (Kahfi, 2017). Thobroni, \& Ahmad Yusam (2015), Judul "Internalisasi Nilai-nilai Kesadaran Lingkungan melalui Pendidikan Perspektif Alquran Hadis," Penerbit Halaqoh Nasional dan Seminar Internasional Pendidikan Islam Fakultas Tarbiyah dan Keguruan UIN Sunan Ampel Surabaya. Prosiding ini dilakukan oleh para pakar kesehatan dan lingkungan. Berdasarkan ilmu profan yang sekularistik yang merupakan derivasi dari realitas rasional dengan kajian nilai-nilai profetis Islam (Thobroni, 2015). Darmalaksana, Wahyudin (2019), Judul "Hadis tentang Lingkungan Hidup," Penerbit Fakultas Ushuluddin UIN Sunan Gunung Djati Bandung. Pada tulisan ini terdapat tiga pola berpikir yaitu berpikir induktif, berpikir deduktif, dan berpikir logis dengan menerapkan metode design thinking hadis. Tulisan ini merupakan template pembelajaran hadis dengan metode desain thinking (Darmalaksana, Hadis tentang Lingkungan Hidup, 2019). Mustabsyiratul Ailah, \& Muh. Ridwan (2019), Judul “Aktualisasi Makna al-Tuhuru Shatru al-Iman melalui Bank Sampah dalam meningkatkan Kesehatan Lingkungan," Penerbit Raushan Fikr. Artikel ini membahas kegiatan pengelolaan limbah yang dilakukan masyarakat. Metode penulisan ini menggunakan literatur riview dengan mengintegrasikan berbagai literatur ilmu pengetahuan umum dan nilai-nilai ajaran Islam (Ailah \& Ridwan, 2019).

Berbagai penelitian terdahulu berharga dalam penyusunan kerangka berpikir penelitian ini. Kerusakan lingkungan adalah akibat perbuatan manusia, dan oleh karena itu manusia harus bertanggung jawab di dunia dan akhirat (Thobroni, 2015). Produksi sampah terus menerus meningkat seiring dengan pertambahan jumlah penduduk, perubahan pola konsumsi, dan gaya hidup masyarakat (Kahfi, 2017). Kebersihan dalam ajaran Islam merupakan prioritas paling utama (Ailah \& Ridwan, 2019). Beberapa teks sumber hukum tentang kebersihan menegaskan bahwa kebersihan sangat 
Jurnal Riset Agama, Volume 1, Nomor 2 (Agustus 2021): 323-337

Muhammad Daffa/Solusi Pengolahan Sampah dalam Problem Pencemaran

Bumi untuk Kebersihan Lingkungan Hidup: Studi Syarah Hadis

ditekankan dalam Islam. Pentingnya kebersihan dijelaskan dalam hadits kebersihan yang menjelaskan bahwa suci itu setengahnya iman (Jazariyah, 2019). Dalam Islam terdapat ungkapan yang sangat familiar dan populer yaitu "kebersihan adalah sebagian dari iman" (Kahfi, 2017). Hadis ini sangat popular bahwa menjaga lingkungan merupakan hal fundamental dalam kesempurnaan seseorang (Darmalaksana, Hadis tentang Lingkungan Hidup, 2019). Kegiatan menciptakan lingkungan yang bersiah salah satunya dapat dilakukan dengan pengelolaan sampah. Berdasarkan Undang-Undang Nomor 18 Tahun 2008, pengelolaan sampah dinyatakan sebagai usaha dan kegiatan yang sistematis, menyeluruh, dan berkesinambungan yang yang terdiri dari dua bagian yaitu pengurangan dan penanganan sampah (Kahfi, 2017). Pengelolaan sampah dilakukan dengan cara menampung, memilah dan menyalurkan sampah (Ailah \& Ridwan, 2019). Sementara itu, diketahui bahwa sampah plastik merupakan limbah yang paling pelik diatasi. Solusi mengatasi sampah plastik antara lain edukasi bahaya limbah plastik, aksi komunitas meminimalisir tumpukan sampah plastik, dan kampanye go green dengan tindakan nyata, khususnya mengubah spanduk bahan plastik untuk didesain dari bahanbahan yang ramah lingkungan (Darmalaksana, Hadis tentang Lingkungan Hidup, 2019).

Berdasarkan paparan di atas, penulis berusaha menyusun formula penelitian, yaitu rumusan masalah, pertanyaan penelitian, dan tujuan penelitian (Darmalaksana, Formula Penelitian Pengalaman Kelas Menulis, 2020). Rumusan masalah penelitian ini adalah terdapat hadis terkait kebersihan. Pertanyaan utama penelitian ini adalah bagaimana hadis tentang kebersihan dan menciptakan kebersihan melalui pengelolaan sampah. Sedangkan pertanyaan secara terperinci yaitu bagaimana pandangan umum kebersihan, bagaimana syarah hadis tentang kebersihan, dan bagaimana menciptakan kebersihan melalui pengelolaan sampah. Tujuan penelitian ini yakni membahas hadis tentang kebersihan. Penelitian ini diharapkan memiliki manfaat bagi pengayaan khazanah pengetahuan Islam.

\section{Metode Penelitian}

Penelitian ini menggunakan pendekatan kualitatif melalui studi Pustaka (Darmalaksana, Metode Penelitian Kualitatif Studi Pustaka dan Studi Lapangan, 2020). Pengujian kualitas hadis digunakan metode takhrij dan syarah hadis (Darmalaksana, Prosiding Proses Bisnis Validitas Hadis untuk Perancangan Aplikasi Metode Tahrij, 2020). Adapun syarah hadis diterapkan pendekatan kontemporer secara kontekstual (Darmalaksana, Penelitian Hadis Metode Syarah Pendekatan Kontemporer: Sebuah Panduan Skripsi, Tesis, dan Disertasi, 2020). 
Jurnal Riset Agama, Volume 1, Nomor 2 (Agustus 2021): 323-337

Muhammad Daffa/Solusi Pengolahan Sampah dalam Problem Pencemaran

Bumi untuk Kebersihan Lingkungan Hidup: Studi Syarah Hadis

\section{Hasil dan Pembahasan Penelitian}

Hasil dan pembahasan penelitian di bawah ini.

\section{Pandangan Umum tentang Kebersihan}

Kerusakan lingkungan seringkali diakibatkan oleh pengelolaan sampah yang kurang tepat. Sampah merupakan salah satu jenis biomassa yang ketersediaannya dari hari ke hari cukup melimpah, terutama di kota besar. Sampah juga menjadi perhatian banyak pihak, karena berhubungan langsung dengan kebersihan dan keindahan (estetika) lingkungan dan kesehatan masyarakat (Simanjuntak, 2019). Sampah memiliki kaitan dengan kegiatan-kegiatan yang dilakukan oleh masyarakat. Selain itu, ada pengertian lainnya yaitu sampah merupakan sisa-sisa dari benda atau beberapa kebutuhan manusia lainnya yang sudah tidak terpakai atau diharuskan untuk dibuang karena sudah habis terpakai untuk kebutuhan sehari-hari (Khairunnisa, 2019). Kegiatan dan kebutuhan sehari-hari manusia berpotensi untuk menghasilkan sampah. Menurut definisi World Health Organization (WHO) sampah adalah sesuatu yang tidak digunakan, tidak dipakai, tidak disenangi atau sesuatu yang dibuang yang berasal dari kegiatan manusia dan tidak terjadi dengan sendirinya (Dobiki, 2018). Maka terdapat pula definisi tentang sampah berdasarkan Udang-Undang No. 18 Tahun 2008. Definisi sampah menurut UU No. 18 Tahun 2008 tentang Pengelolaan Sampah, sampah adalah sisa kegiatan sehari-hari manusia dan/atau proses alam yang berbentuk padat. Sedangkan SNI 13-1990-F mendefinisikan sampah sebagai limbah yang bersifat padat, terdiri dari zat organik dan zat anorganik yang dianggap tidak berguna lagi dan harus dikelola agar tidak membahayakan lingkungan dan melindungi investasi pembangunan. Menurut Ditjen Cipta Karya Departemen Pekerjaan Umum (2007), sampah merupakan suatu buangan atau produk sisa dalam bentuk padat sebagai akibat kegiatan manusia yang dapat dianggap sudah tidak bermanfaat lagi, untuk itu harus dikelola agar tidak membahayakan lingkungan dan kesehatan manusia (Simanjuntak, 2019).

Beragam kegiatan yang dilakukan manusia menjadikan sumber sampah dapat beragam pula. Sampah tidak hanya berasal dari sisa-sisa kebutuhan rumah tangga saja, tetapi juga dapat berasal dari kegiatan lainnya, seperti industri, pertambangan, pertanian, perternakan, perikanan, transportasi, perdagangan dan lain sebagainya. Beberapa pengertian tersebut dapat diambil suatu kesimpulan bahwasanya sampah merupakan sisa-sisa atau hasil akhir dari suatu benda ataupun produk yang sudah tidak diperlukan dan diharuskan untuk dibuang ke tempat pembuangan akhir. Sampah dibagi menjadi dua kategori besar, yaitu sampah organik dan sampah anorganik (Khairunnisa, 2019). Secara sederhana, sampah merupakan materi, bahan maupun segala sesuatu yang tidak diinginkan, baik itu merupakan sisa atau residu maupun buangan. Meski demikian, 
Jurnal Riset Agama, Volume 1, Nomor 2 (Agustus 2021): 323-337

Muhammad Daffa/Solusi Pengolahan Sampah dalam Problem Pencemaran

Bumi untuk Kebersihan Lingkungan Hidup: Studi Syarah Hadis

dalam konsep perundang-undangan, sampah dapat pula muncul, ada maupun timbul akibat proses alam yang berbentuk padat. Hal ini berbeda dalam pandangan Rudi Hartono yang memandang bahwa sampah tidak muncul akibat proses alam, atau dengan kata lain bahwa materi-materi yang muncul akibat proses alam tidaklah dinamakan sampah, sebab yang ada hanyalah produk-produk yang tidak bergerak (Kahfi, 2017). Kegiatan serta kebutuhan manusia dapat mempengaruhi lingkungan yang berkaitan dengan proses pada alam. Lingkungan hidup sebenarnya selalu dilihat setiap saat, seperti halnya yang ada di sekeliling ini, adalah merupakan lingkungan. Istilah lingkungan jarang sekali digunakan dalam kerangka etimologi maupun terminologi. Pandangan Yusuf al-Qardawi misalkan, dalam mendefenisikan lingkungan di sini adalah sebuah lingkup dimana manusia hidup, ia tinggal di dalamnya, baik ketika bepergian ataupun mengasingkan diri. Sebagai tempat manusia kembali, baik dalam keadaan rela ataupun terpaksa (Kumala, 2020).

Menurut laporan Menteri Lingkungan Hidup dan Kehutanan, tahun 2019 Indonesia dapat menghasilkan 66-67 juta ton sampah. Data ini mengindikasikan bahwasanya sampah yang dihasilkan oleh masyarakat Indonesia meningkat dari tahun sebelumnya yang hanya berjumlah 64 juta ton menjadi 66-67 juta ton sampah. Sampah ini didominasi oleh 60\% sampah organik dan 15\% sampah plastik. Selain itu, menurut data yang diperoleh dari The World Bank tahun 2018 menyebutkan bahwasanya 87 kota di pesisir Indonesia membuang sampah ke lautan yang diperkirakan sebanyak 1,27 juta ton sampah dengan kategori 9 juta ton merupakan sampah plastik dan 3,2 juta ton dari sampah plastik tersebut merupakan sampah sedotan (Khairunnisa, 2019). Permasalahan-permasalahan tersebut baik yang berasal dari keberadaan sampah itu sendiri, maupun yang terkait dengan penumpukan serta pengelolaannya, lebih jauh lagi akan membawa dampak dampak baru. Misalnya saja, dari sudut pandang estetika (kebersihan dan keindahan kota) maupun dari sudut sanitasi (kesehatan lingkungan). Tumpukan sampah yang tersebar tanpa mengenal tempat, memberikan kesan jorok, kotor, kumuh maupun rantasa' (Kahfi, 2017). Sampah yang semakin tidak diatasi berpengaruh pada kesehatan lingkungan. Penyebaran bau busuk dan risiko timbulnya vektor penyakit belum mengindikasikan totalitas implementasi makna al-Tuhuru Shatru alIman (kesucian atau kebersihan sebagian dari iman), karena keimanan seorang muslim akan menghadirkan rasa aman bagi orang lain dan lingkungan sosialnya, sedangkan penyebaran bau busuk dan risiko penyebaran vektor penyakit akibat Open Dumping pada TPA menunjukkan suatu yang kontradiktif dari implementasi keimanan seorang muslim. Oleh karena itu dibutuhkan alernatif lain yang lebih efisien dalam penanganan sampah (Ailah \& Ridwan, 2019). 
Jurnal Riset Agama, Volume 1, Nomor 2 (Agustus 2021): 323-337

Muhammad Daffa/Solusi Pengolahan Sampah dalam Problem Pencemaran

Bumi untuk Kebersihan Lingkungan Hidup: Studi Syarah Hadis

\section{Syarah Hadis tentang Kebersihan}

Terdapat hadis Nabi Saw. berkenaan dengan kebersihan pada kitab ad-Darimi Nomor 615:

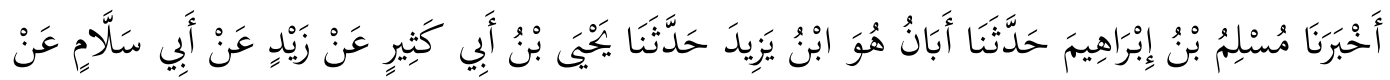

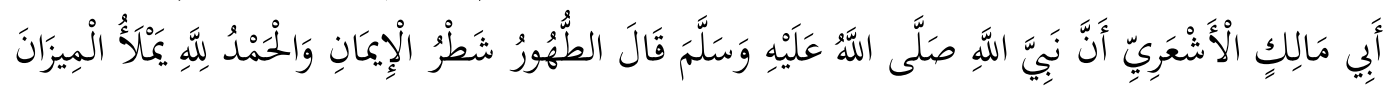

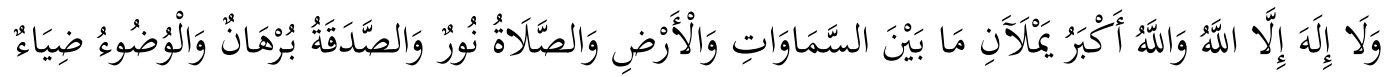

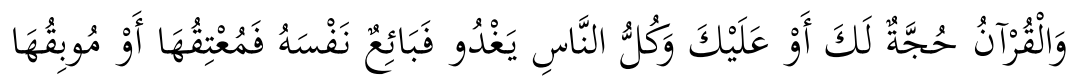

Telah mengabarkan kepada kami Muslim bin Ibrahim telah menceritakan kepada kami Aban Ibnu Yazid, telah menceritakan kepada kami Yahya bin Abu katsir dari Zaid dari Abu Salam dari Abu Malik alAsy'ari Nabi shallallahu 'alaihi wasallam bersabda: "Kebersihan adalah setengah keimanan, dan (ucapan) alhamdulillah memenuhi timbangan, dan (kalimat) laa ilaaha illallahu wa allahu akbar keduanya memenuhi langit dan bumi, salat adalah cahaya, sedekah bukti, wudu itu sinar, dan alQur'an dapat menjadi hujjah yang membelamu atau hujjah yang menuntutmu, seluruh manusia berpagi hari, lantas menjual dirinya, hingga ia memerdekakan dirinya atau membinasakannya" (HR. ad-Darimi).

Mula-mula dilakukan pencarian melalui aplikasi hadis dengan kata kunci "Kebersihan" hingga ditemukan hadis pada kitab ad-Darimi Nomor 615.

Tabel 1 Daftar Rawi Sanad

\begin{tabular}{|c|c|c|c|c|c|c|}
\hline \multirow[t]{2}{*}{ No. } & \multirow[t]{2}{*}{ Rawi Sanad } & Lahir/Wafat & \multirow[t]{2}{*}{ Negeri } & \multirow[t]{2}{*}{ Kuniyah } & $\begin{array}{l}\text { Komentar } \\
\text { Ulama }\end{array}$ & \multirow[t]{2}{*}{ Kalangan } \\
\hline & & $\mathbf{W}$ & & & + & \\
\hline 1 & Abu Malik & $18 \mathrm{H}$ & Syam & $\begin{array}{l}\text { Abu } \\
\text { Malik }\end{array}$ & Sahabat & Sahabat \\
\hline 2 & Mamthur & & Syam & $\begin{array}{l}\text { Abu } \\
\text { Sallam }\end{array}$ & Tsiqah & $\begin{array}{l}\text { Tabi'in } \\
\text { kalangan } \\
\text { biasa }\end{array}$ \\
\hline 3 & $\begin{array}{l}\text { Zaid bin } \\
\text { Sallam bin } \\
\text { Abi Salam } \\
\text { Mamthur } \\
\end{array}$ & & Syam & & Tsiqah & Tabi'in \\
\hline 4 & $\begin{array}{l}\text { Yahya bin } \\
\text { Abi Katsir } \\
\text { Shalih bin }\end{array}$ & $132 \mathrm{H}$ & Yamamah & $\begin{array}{l}\text { Abu } \\
\text { Nashr }\end{array}$ & Tsiqah & Tabi'in \\
\hline
\end{tabular}


Jurnal Riset Agama, Volume 1, Nomor 2 (Agustus 2021): 323-337

Muhammad Daffa/Solusi Pengolahan Sampah dalam Problem Pencemaran

Bumi untuk Kebersihan Lingkungan Hidup: Studi Syarah Hadis

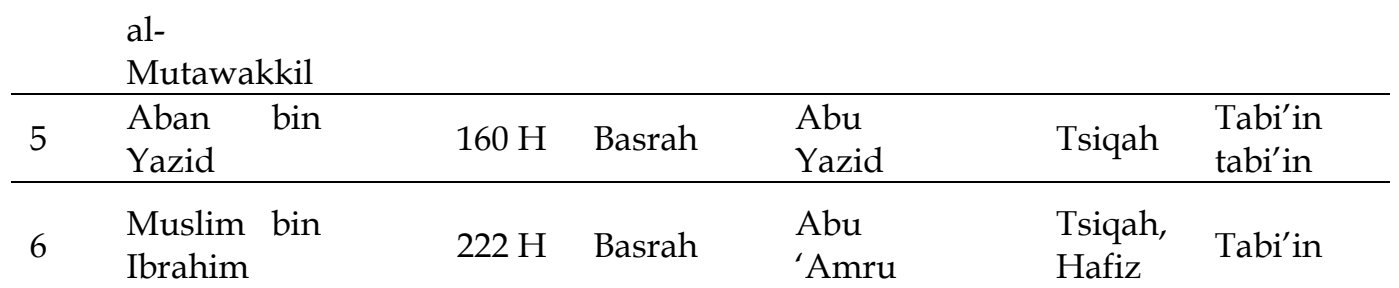

Tabel 1 adalah daftar rawi dan sanad dari hadis yang sedang diteliti. Pemasangan seluruh rangkaian jalur sanad dapat dilihat pada bagian di atas. Hal ini dilakukan agar lebih memudahkan melihat posisi setiap periwayat terhadap hadis tersebut. Ilmu hadits adalah ilmu yang sangat memperhatikan sanad hadits, yang mana sanad merupakan hal yang spesifik dan keutamaan yang dimiliki umat ini, yang tidak dimiliki umatumat lain sebelumnya (Shafwan \& Hambal, 2020). Pertama, peneliti harus menentukan terlebih dahulu teks hadis yang akan diteliti. Kedua, pentahrij menelusuri sebaran hadis pada kitab-kitab hadis melalui aplikasi Maktabah Syamilah. Ketiga, merekap teks hadis yang tersebar pada kitab-kitab hadis lengkap dengan rawi dan sanad. Keempat, hadis-hadis yang ditemukan di Maktabah Syamilah disusun berdasarkan rawi sanad. Kelima, membuat matrik generasi periwayat hadis dengan skala nomor, nama rawi, tahun lahir dan tahun wafat, kualifikasi meliputi jarh dan ta'dil, dan pencantuman generasi. Susunan generasi periwayat adalah: Sahabat $80 \mathrm{H}$ (S); Tabi' in $130 \mathrm{H}$ (T); Tabi tabi' in $180 \mathrm{H}$ (T2); Tabi tabi tabi' in 230 H (T3); Tabi tabi tabi tabi' in 300 H (T4); Tabi tabi tabi tabi tabi'in 360 H (T5); Tabi tabi tabi tabi tabi tabi'in $420 \mathrm{H}$ (T6); dan Tabi tabi tabi tabi tabi tabi (T7) (Darmalaksana, Prosiding Proses Bisnis Validitas Hadis untuk Perancangan Aplikasi Metode Tahrij, 2020). Di antara ulama tabi'in yang terkenal atau yang biasa disebut al-fuqaha' al-sab'ah (tujuh fuqaha') adalah: Said bin Musayyib, Qasim bin Muhammad, Urwah bin Zubair, Kharijah bin Zaid, Abu Salamah bin Abdirrahman, Ubaidullah bin Abdillah bin Utbah dan Sulaiman bin Yasar (Shafwan \& Hambal, 2020).

Kajian sanad dalam ilmu hadis merupakan konsep dasar yang perlu dipahami dan dianalisis kembali guna mengokohkan kajian keislaman. Sanad dalam ilmu hadis merupakan sandaran atau jalur periwayatan hadits yang memiliki peranan penting dalam menentukan kualitas dan kuantitas suatu hadits (Dozan, Turmuzi, \& Sugitanata, 2020). Pentingnya posisi hadis tehadap al-Qur'an turut menempatkan posisi syarah hadis sebagai sesuatu yang tidak dapat diabaikan. Teks-teks hadis yang ada menjadi penjelas atas teks-teks al-Qur'an yang dianggap masih bersifat global. Syarah memegang peranan penting untuk menjelaskan hal-hal yang dianggap masih umum, sulit dipahami, terlihat bertentangan, maupun halhal yang menyimpan keganjilan dalam teks-teks hadits (Melita, 2018). Akan tetapi, takhrij hadis dan sekaligus syarah hadis pasti menghasilkan lembar 
Jurnal Riset Agama, Volume 1, Nomor 2 (Agustus 2021): 323-337

Muhammad Daffa/Solusi Pengolahan Sampah dalam Problem Pencemaran

Bumi untuk Kebersihan Lingkungan Hidup: Studi Syarah Hadis

halaman yang tebal. Sehingga hal ini dibutuhkan dua penelitian terpisah, yakni penelitian takhrij hadis dan penelitian syarah hadis. Meskipun penelitian takhrij hadis biasanya telah dicantumkan pula syarah hadis sederhana. Walaupun penelitian syarah hadis pun dituntut takhrij hadis secara sederhana (Darmalaksana, Penelitian Hadis Metode Syarah Pendekatan Kontemporer: Sebuah Panduan Skripsi, Tesis, dan Disertasi, 2020).

Secara umum, syarat hadis sahih adalah para periwayat harus tsiqah yakni adil dan dhabit serta sanad harus bersambung (Darmalaksana, Prosiding Proses Bisnis Validitas Hadis untuk Perancangan Aplikasi Metode Tahrij, 2020). Pada hadis ini tampak tidak ada pandangan ulama yang memberikan komentar negatif terhadap para periwayat. Ibnu Qayyim menyatakan bahwa tidak ada alasan untuk menolak hadis yang periwayatnya tsiqah, walaupun itu menyendiri (fard), apabila tidak mengandung perlawanan dengan hadis lain yang periwayatnya lebih tsiqah (Idris, 2015). Juga sanad hadis ini dapat dikatakan bersambung dengan penilaian antara guru dan murid bertemu atau sezaman, meskipun tampak ada periwayat yang tidak diketahui tahun lahir dan wafat. Namun, antara guru dan murid dapat diperkirakan bertemu atau sezaman bila usia masing-masing periwayat berkisar 90 tahun (Sabilah, Darmalaksana, Nurdianawati, \& Tamami, 2021). Melihat daftar rawi dan sanad maka dapat diputuskan status hadis ini shahih.

Hadis di atas menyatakan bahwa bersuci adalah setengah dari iman. Hal ini berkaitan dengan keimanan seseorang yang menjadi lengkap apabila seseorang itu dapat menjaga kebersihan (Agustina, 2021). Sebenarnya hadis yang sahih berbunyi: "at-Tahuru syatru al-Iman" artinya: Kebersihan sebagian dari iman. Maksudnya setengah iman (Erwan, 2008). Hadis sahih dari Nabi Saw. yang mirip dengan "Kebersihan sebagian dari iman." Hadis itu adalah sabda Nabi Saw. yang berbunyi, "ath-Thahuuru syatrul iimaan" (Wijaya, 2015). Arti kata "al-Tuhuru" berarti suci, dapat juga diartikan bersih. Namun "suci" dan "bersih" mengandung arti yang berbeda secara bahasa. Dalam Bahasa Arab "al-Tuhuru" artinya suci secara lahir dan batin, mensucikan pikiran, hati, anggota badan dan segala yang nampak secara lahiriyah. Sedangkan bersih dalam Bahasa Arab yaitu "alNazafah" yaitu kebersihan yang nampak secara lahiriyah saja (Ailah \& Ridwan, 2019). Menurut Imam an-Nawawi redaksi hadis al-Tahuru syatru al-Iman ini boleh dibaca dengan memberikan harakat dhommah pada huruf tha', yakni al-Tahuru dan boleh dibaca al-Tuhuru, dengan harakat fathah pada huruf tha'. Dari kedua redaksi di atas, redaksi yang paling mashur adalah redaksi pertama, yakni al-Tuhuru syatru al-Iman. Walaupun demikian, dalam penelitian ini istilah yang penulis pergunakan adalah redaksi yang kedua, yakni al-Tahuru syatru al-Iman (Hakim, 2014). Yusuf Al-Qardawi menjelaskan bahwa kebersihan harus diberikan 
Jurnal Riset Agama, Volume 1, Nomor 2 (Agustus 2021): 323-337

Muhammad Daffa/Solusi Pengolahan Sampah dalam Problem Pencemaran

Bumi untuk Kebersihan Lingkungan Hidup: Studi Syarah Hadis

perhatian yang lebih, hal ini didasarkan dengan pertimbangan penting yaitu kebersihan merupakan hal yang disukai oleh Allah Swt. Rasulullah sallallahu 'alaihi wa sallam sangat peduli terhadap kebersihan dari segala aspek seperti rohani, jasmani, pakaian, bahkan kebersihan lingkungan (Ailah \& Ridwan, 2019).

Para ulama hadis dalam mensyarah hadis dengan cara menunjukkan makna yang sebenarnya, terkait dengan keilmuan mereka. Mereka juga berkomitmen untuk menjaga hadis agar tetap bisa dijadikan landasan dalam menjalani kehidupan sesuai dengan agama (Kurniati, 2020). Islam mengajarkan cakupan yang luas berkaitan dengan menjaga kebersihan. Sebagaimana disinggung dalam al-Qur'an, Islam mengajarkan kebersihan mencakup aspek rohani dan jasmani (Agustina, 2021). Implementasi Islam yang bersumber dari al-Qur'an dan sunnah ini memiliki konsep tentunya terhadap kebersihan sebagian dari iman dalam aktualisasinya dengan solusi metode yang Islami. Agama dan ajaran Islam menaruh perhatian amat tinggi pada kebersihan, baik lahiriyah (fisik) maupun batiniyah (psikis). Kebersihan lahiriyah itu tidak dapat dipisahkan dengan kebersihan batiniyah. Oleh karena itu, ketika seorang muslim melaksanakan ibadah tertentu harus membersihkan terlebih dahulu aspek lahiriyahnya. Ajaran Islam yang memiliki aspek akidah, ibadah, muamalah, dan akhlak ada kaitan dengan seluruh kebersihan ini (Wijaya, 2015). Dalam hadis tersebut dinyatakan bersuci adalah setengah dari iman. Hal ini berkaitan dengan keimanan seseorang yang menjadi lengkap apabila seseorang itu dapat menjaga kebersihan (Agustina, 2021). Kebersihan dalam Islam sangat dianjurkan oleh Rasulullah Saw. karena dengan melakukan kebersihan akan terhindar dari beberapa penyakit yang menyebabkan aktivitas sehari-hari terganggu khususnya dalam melakukan ibadah. Seperti halnya jika hendak melaksanakan shalat maka pertama yang diperhatikan adalah bersuci terlebih dahulu baik dari badan, pakaian maupun tempat (Rohmah, 2017). Bersandar pada pemaknaan taharah, maka perilaku senantiasa menjaga kebersihan lingkungan dengan cara membuang sampah pada tempatnya merupakan salah satu akhlak terpuji (Ailah \& Ridwan, 2019).

\section{Menciptakan Kebersihan melalui Pengelolaan Sampah}

Pengelolaan sampah serta kebersihan dapat sejalan dengan ajaran Islam. Di satu sisi pandangan semacam ini perlu mendapat respon dalam mendudukan penelitian hadis secara proporsional, dan disi lain perlu dilakukan pembahasan prinsip serta operasional metode syarah hadis dengan pendekatan ilmu-ilmu sosial dalam pengembangan ilmu hadis. Pastinya, melalui penelitian hadis metode syarah inilah analisis dengan pendekatan ilmu-ilmu sosial terbuka pintunya (Darmalaksana, Studi Penggunaan Analisis Pendekatan Ilmu-ilmu Sosial dalam Penelitian Hadis 
Jurnal Riset Agama, Volume 1, Nomor 2 (Agustus 2021): 323-337

Muhammad Daffa/Solusi Pengolahan Sampah dalam Problem Pencemaran

Bumi untuk Kebersihan Lingkungan Hidup: Studi Syarah Hadis

Metode Syarah, 2020). Sebagaimana hubungan antara tata cara pengelolaan lingkungan yang diriwayatkan oleh at-Tirmidzi berikut:

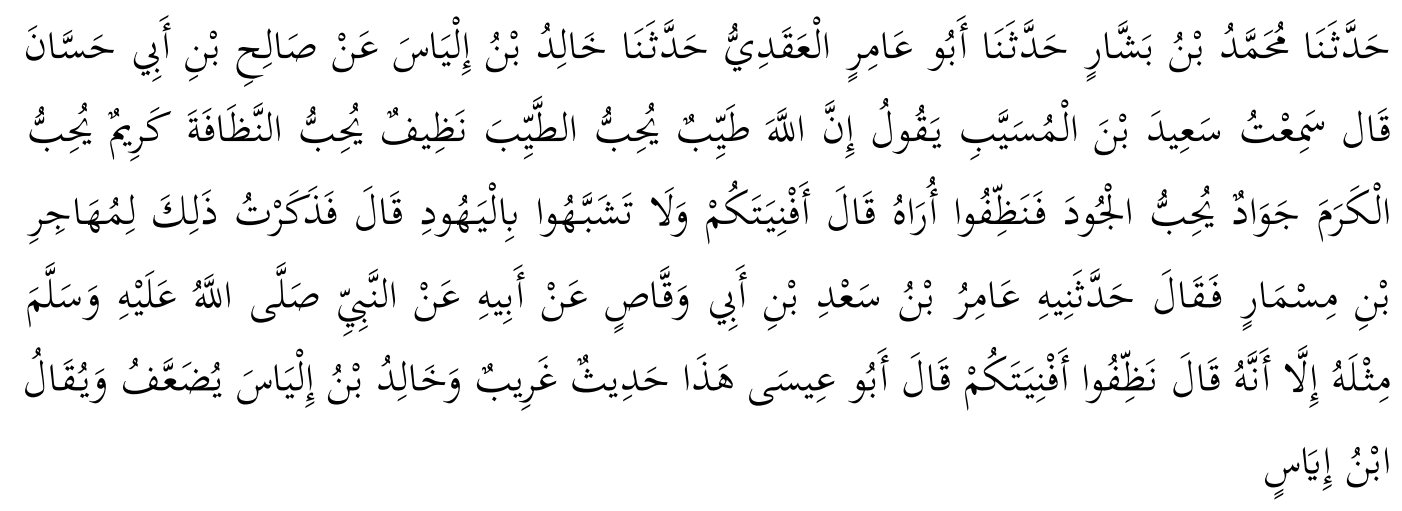

Telah menceritakan kepada kami Muhammad bin Basyar telah menceritakan kepada kami Abu 'Amir al-'Aqadi telah menceritakan kepada kami Khalid bin Ilyas dari Shalih bin Abu Hassan ia berkata; Aku mendengar Sa'id bin al-Musayyab berkata; "Sesungguhnya Allah Maha Baik, dan menyukai kepada yang baik, Maha Bersih dan menyukai kepada yang bersih, Maha Pemurah, dan menyukai kemurahan, dan Maha Mulia dan menyukai kemuliaan, karena itu bersihkanlah diri kalian, "aku mengiranya dia berkata; "Halaman kalian, dan janganlah kalian menyerupai orang-orang Yahudi," Shalih bin Abu Hassan berkata; Hadits itu aku sampaikan kepada Muhajir bin Mismar, lalu dia berkata; "Amir bin Sa'ad bin Abu Waqqas telah menceritakannya kepadaku dari ayahnya dari Nabi shallallahu 'alaihi wasallam dengan hadits yang semisal, namun dalam hadits tersebut beliau bersabda: "Bersihkanlah halaman kalian." Abu Isa berkata; Hadits ini gharib, dan Khalid bin Ilyas telah dilemahkan, dan dia juga dinamakan Ibnu Iyas (At-Tirmidzi).

Pengelolaan sampah yang baik perlu dilakukan untuk menjaga kebersihan lingkungan. Untuk menyelesaikan masalah pencemaran lingkungan ini, tentunya harus mengetahui sumber pencemar dan bagaimana proses pencemar itu terjadi, serta langkah penyelesaian pencemaran itu sendiri. Infrastruktur lain dapat juga dipengaruhi oleh pengelolaan sampah yang tidak memadai, seperti tingginya biaya yang diperlukan untuk pengolahan air (Graita, 2020). Penyuluhan tentang pengelolaan sampah dapat merubah persepsi dan pandangan masyarakat tentang peran mereka terhadap pengelolaan sampah. Dalam sosialisasi dan penyuluhan tentang sampah tersebut, warga diberikan edukasi dan fasilitas untuk memilah sampah. Warga diminta memilah sampah layak jual dalam 3 (tiga) kategori utama yakni: plastik, kertas/dupleks, dan bungkus kemasan (Muryani, Widiarti, \& Savitri, 2020). Sebagai upaya 
Jurnal Riset Agama, Volume 1, Nomor 2 (Agustus 2021): 323-337

Muhammad Daffa/Solusi Pengolahan Sampah dalam Problem Pencemaran

Bumi untuk Kebersihan Lingkungan Hidup: Studi Syarah Hadis

dalam penyelenggaraannya, pemerintah daerah menyediakan sarana dan prasarana yang dibutuhkan oleh masyarakat sebagaimana diatur di dalam pasal 9 dan sebagai upaya dalam mengatasi permasalahan pengelolaan sampah. Pemerintah daerah melarang setiap orang atau badan membuang sampah sembarangan hal ini diatur di dalam pasal 39 yang berbunyi: Pasal 39 (1) Setiap orang atau badan, dalam pengelolaan sampah dilarang: Memasukan sampah dari luar daerah ke dalam wilayah daerah; Mengimpor sampah; Mencampur sampah dengan limbah B3; Mengelola sampah yang menyebabkan pencemaran dan/atau perusakan lingkungan; Membuang sampah tidak pada tempat yang telah ditentukan dan disediakan; Melakukan penanganan sampah dengan pembuangan terbuka di tempat pemrosesan akhir dan atau; Membakar sampah yang tidak sesuai dengan persyaratan teknis pengelolaan sampah, PERDA Nomor 9 tahun 2015 (Fadillah \& Suryani, 2020).

Dari sekian banyak efek negatif yang ditimbulkan oleh sampah ada juga efek positifnya yang dapat diambil dari sampah tersebut, salah satunya yaitu dengan mendaur ulang sampah plastik tersebut. Daur ulang merupakan proses pengambilan barang yang masih memiliki nilai dari sampah untuk digunakan kembali (Musyahidah, Prasanti, Hasanah, \& Ferdiawan, 2020). Pendekatan komunitas pengelola sampah terpadu yang dibentuk ini merupakan manifestasi dari sistem 3R yang saat ini sudah merupakan konsensus internasional yaitu: reduce, reuse, recycle atau 3M (Mengurangi, menggunakan kembali, mendaur ulang). Terdapat beberapa modifikasi dalam program ini menjadi $6 \mathrm{M}$ dan $2 \mathrm{TM}$. Masyarakat yang bergabung dalam komunitas ini secara bertahap akan digiring untuk melakukan pengelolaan sampah secara sadar dan mandiri dengan menerapkan $6 \mathrm{M}$ dan 2 TM yakni: Mengurangai potensi sampah, memanfaatkan sampah, mendaur ulang sampah, memilah sampah, menabung sampah, meminimalkan sampah residu masuk ke TPA, tidak Membuang sampah ke sungai, dan tidak membakar sampah (Muryani, Widiarti, \& Savitri, 2020). Itu jelas satu implementasi dari pada ajaran dasar Islam untuk dilakukan selamanya di tengah masyarakat. Di tempat lain Nabi Saw. bersabda bahwa kebersihan adalah bagian dari iman. Hadis tersebut menunjukkan bahwa kebersihan sebagai salah satu elemen dari pemeliharaan lingkungan (ri'ayah al-bi'ah) merupakan bagian dari iman. Sehingga kemaslahatan dapat terwujud (Graita, 2020).

Berdasarkan pemaparan di atas dapat disimpulkan bahwa secara garis besar, kegiatan di dalam pengelolaan sampah meliputi penyimpanan sampah, pengumpulan sampah, pengolahan dan pembuangan akhir (Hermawan, 2020). Pengetahuan yang didapat oleh mitra dari hasil edukasi bank sampah adalah tentang apa itu bank sampah, bagaimana cara mendirikan bank sampah dan mekanisme kerja bank sampah. Masalah sampah di berbagai kota di Indonesia dapat dipecahkan dengan baik 
Jurnal Riset Agama, Volume 1, Nomor 2 (Agustus 2021): 323-337

Muhammad Daffa/Solusi Pengolahan Sampah dalam Problem Pencemaran

Bumi untuk Kebersihan Lingkungan Hidup: Studi Syarah Hadis

apabila peran aktif masyarakat meningkat (Muryani, Widiarti, \& Savitri, 2020). Selain itu pengelolaan sampah organisasi persampahan dan kelompok masyarakat yang bergerak di bidang persampahan dapat juga diikut sertakan dalam kegiatan pengelolaan dan pelayanan sampah dalam rangka menyelengarakan pelayanan persampahan secara terpadu dan komperhensif, pemenuhi hak dan kewajiban masyarakat, serta tugas dan wewenang pemerintah dan pemerintahan daerah itu melaksanakan pelayanan publik, diperlukan payung hukum dalam bentuk UndangUndang (Graita, 2020). Dengan demikian program pengelolaan sampah ini dapat dilakukan di setiap tahapan sistem pengelolaan sampah. Idealnya dengan pengurangan sampah ini sudah dapat dimulai sejak awal dari sumbernya, yaitu sejak pewadahan sebagai bagian dari subsistem terdepan. Hal ini berhubungan langsung dengan peran serta masyarakat sebagai penghasil sampah itu sendiri (Muryani, Widiarti, \& Savitri, 2020).

Kampenye lingkungan hidup yang bersih perlu dilakukan dalam mengatasi masalah sampah, khususnya limbah plastik. Diketahui bahwa sampah plastik merupakan limbah yang tidak mudah diurai. Seluruh negara di belahan dunia memiliki problem besar terkait dengan tumpukan sampah plastik. Adapun solusi mengatasi sampah plastik dapat dilakukan dengan beberapa kegiatan lapangan, pertama, edukasi di masyarakat tentang bahaya limbah plastik, kedua, aksi berbagai komunitas untuk meminimalisir tumpukan sampah plastik di berbagai tempat, termasuk di perairan laut, dan ketiga, kampanye go green dengan tindakan riil dan nyata, misalnya mengubah spanduk bahan plastik yang banyak digunakan dalam berbagai kegiatan untuk didesain dari bahan-bahan yang lebih ramah lingkungan (Darmalaksana, Hadis tentang Lingkungan Hidup, 2019).

\section{Kesimpulan}

Konsep pengolahan sampah menurut hadis yang menjadi penelitian ini disajikan menurut susunan kerangka berpikir yang mencakup pandangan umum tentang kebersihan, hadis tentang kebersihan, dan menciptakan kebersihan melalui pengelolaan sampah. Berdasarkan pandangan umum kebersihan diketahui bahwa pengelolaan sampah yang baik sejalan dengan ajaran Islam. Dalam melakukan aktifitas pengelolaan sampah menjadi perlu dilakukan. Meliputi penyimpanan, pengumpulan, pengolahan, hingga pembuangan akhir. Pengelolaan yang bertanggung jawab, menjadikan sampah dapat dimanfaatkan. Hadis tentang kebersihan menyebutkan bahwa perilaku pengelolaan lingkungan sejalan dengan keimanan. Hadis ini memiliki sanad yang tsiqah dan dapat dipercaya. Syarah hadis ini menurut para ulama memiliki kaitan dengan ibadah lainnya. Adapun kebersihan menjadi bagian dari keimanan. Dengan demikian konsep pengolahan sampah menurut hadis mencakup edukasi pengelolaan sampah dengan mengurangi, menggunakan kembali, dan 
Jurnal Riset Agama, Volume 1, Nomor 2 (Agustus 2021): 323-337

Muhammad Daffa/Solusi Pengolahan Sampah dalam Problem Pencemaran

Bumi untuk Kebersihan Lingkungan Hidup: Studi Syarah Hadis

mendaur ulang sampah. Diharapkan penelitian ini bermanfaat untuk menambah setitik pengayaan khazanah pengetahuan Islam tentang konsep kebersihan menurut hadis. Diakui penelitian ini memiliki keterbatasan dalam penyususnan kerangka berpikir sehingga membutuhkan penelitian yang lebih komperhensif, integral, dan mendalam. Penelitian ini merekomendasikan pentingnya penyuluhan kepada khalayak muslim bahwa menjaga kebersihan saja belum cukup tetapi diharuskan adanya pengolahan sampah dari tiap masyarakat sebagai penghasil dari sampah.

\section{Daftar Pustaka}

Agustina, A. (2021). Perspektif Hadis Nabi Saw. mengenai Kebersihan Lingkungan. Jurnal Penelitian Ilmu Ushuluddin, 96-104.

Ailah, M., \& Ridwan, M. (2019). Aktualisasi Makna al-Tuhuru Shatru alIman melalui Bank Sampah dalam meningkatkan Kesehatan Lingkungan. Raushan Fikr, 63-82.

At-Tirmidzi. (2021, Mei 1). www.hadits.id. Retrieved from https://www.hadits.id/hadits/tirmidzi/2723

Darmalaksana, W. (2019, December Kamis). Hadis tentang Lingkungan Hidup. Bandung: Fakultas Ushuluddin UIN Sunan Gunung Djati.

Darmalaksana, W. (2020). Formula Penelitian Pengalaman Kelas Menulis. Jurnal Kelas Menulis UIN Sunan Gunung Djati Bandung. Retrieved from http://digilib.uinsgd.ac.id/32620/

Darmalaksana, W. (2020). Metode Penelitian Kualitatif Studi Pustaka dan Studi Lapangan. Pre-Print Digital Library UIN Sunan Gunung Djati Bandung.

Darmalaksana, W. (2020). Penelitian Hadis Metode Syarah Pendekatan Kontemporer: Sebuah Panduan Skripsi, Tesis, dan Disertasi. Diroyah: Jurnal Studi Ilmu Hadis, 58-68.

Darmalaksana, W. (2020). Prosiding Proses Bisnis Validitas Hadis untuk Perancangan Aplikasi Metode Tahrij. Jurnal Ushuluddin UIN Sunan Gunung Djati Bandung, 1-7.

Darmalaksana, W. (2020). Studi Penggunaan Analisis Pendekatan Ilmuilmu Sosial dalam Penelitian Hadis Metode Syarah. Khazanah Sosial, $155-166$.

Dobiki, J. (2018). Analisis Ketersediaan Prasarana Persampahan dI Pulau Kumo dan Pulau Kakara di Kabupaten Halmahera Utara. Spasial: Perencanaan Wilayah dan Kota, 220-228.

Dozan, W., Turmuzi, M., \& Sugitanata, A. (2020). Konsep Sanad dalam Perspektif Ilmu Hadits: Telaah terhadap Kualitas dan Kuantitas Hadits Nabi Muhammad Saw. EL-HIKAM: Jurnal Pendidikan dan Kajian Keislaman, 202-236.

Erwan, A. (2008, Maret 31). Higienitas Perspektif Hadis: Kajian Hadis-hadis tentang Kebersihan Makanan, Sumber Air, Rumah dan Jalanan. Jakarta: 
Jurnal Riset Agama, Volume 1, Nomor 2 (Agustus 2021): 323-337

Muhammad Daffa/Solusi Pengolahan Sampah dalam Problem Pencemaran

Bumi untuk Kebersihan Lingkungan Hidup: Studi Syarah Hadis

UIN Syarief Hidayatullah.

Fadillah, N. P., \& Suryani, I. (2020). Peranan Dinas Lingkungan Hidup dalam Pelaksanaan Peraturan Daerah Kabupaten Dharmasraya Nomor 9 Tahun 2015 Perspektif Fiqih Siyasah Dusturiyah. Jurnal Integrasi Ilmu Syari'ah, 13-26.

Graita, S. A. (2020, Agustus Minggu). Analisis Hukum Pidana Islam dan Kebijakan Perda Nomor 5 Tahun 2014 terhadap Pengelolaan Limbah Tanpa Izin: Studi Lapangan di Dinas Lingkungan Hidup Kota Surabaya. Surabaya: UIN Sunan Ampel.

Hakim, H. (2014, Juni 17). Pengaruh Pemahaman Hadis "Kebersihan adalah sebagian dari Iman" terhadap Perilaku Kebersihan Lingkungan pada Santri di Pondok Pesantren Futuhiyyah Mranggen Demak. Semarang: IAIN Walisongo.

Hermawan, H. (2020, November Selasa). Tinjauan Hukum Islam tentang Upah Pengangkut Sampah. Bandar Lampung: UIN Raden Intan.

Idris, M. (2015). Telaah Kritis terhadap Syaz sebagai Unsur Kaedah Kesahihan Matan Hadis. Tahdis: Jurnal Kajian Ilmu Al-Hadits, 73-92.

Jazariyah, J. (2019). Internalisasi Nilai-nilai Hadits dalam Pendidikan Usia Dini. Masile: Jurnal Studi Ilmu Keislaman, 80-91.

Kahfi, A. (2017). Tinjauan terhadap Pengelolaan Sampah. Jurisprudentie, 1225.

Khairunnisa, D. A. (2019). Budaya Pembuangan Sampah Sembarangan dalam Perspektif Hukum Islam dan Hukum Positif. Jakarta: Fakultas Syariah dan Hukum Universitas Islam Negeri Syarif Hidayatullah .

Kumala, W. (2020). Hukum membuang Sampah di Daerah Aliran Sungai (Das) menurut Fatwa MUI No. 47 Tahun 2014. Medan: Fakultas Syariah dan Hukum Universitas Islam Negeri Sumatera Utara.

Kurniati, Y. (2020). Rekonstruksi Metodologi Keilmuan Syarah Hadis Klasik. Islam Transformatif: Journal of Islamic Studies, 46-56.

Melita, R. (2018). Penerapan Metode Term Frequency Inverse Document Frequency (TF-IDF) dan Cosine Similarity pada Sistem Temu Kembali Informasi untuk mengetahui Syarah Hadits Berbasis Web: Studi Kasus Syarah Umdatil Ahkam. Jakarta: Teknik Informatika Fakultas Sain dan Teknologi UIN Syarif Hidayatullah.

Muryani, E., Widiarti, I. W., \& Savitri, N. D. (2020). Pembentukan Komunitas Pengelola Sampah Terpadu Berbasis Masyarakat. Jurnal Pengabdian dan Pemberdayaan Masyarakat, 117-124.

Musyahidah, S., Prasanti, N. M., Hasanah, U., \& Ferdiawan, F. (2020). Tinjauan Ekonomi Islam pada Prospek Industri Daur Ulang Sampah Plastik. JIEBI: Jurnal Ilmu Ekonomi dan Bisnis Islam, 76-89.

Rohmah, S. N. (2017, November 16). Konsep Kebersihan Lingkungan dalam Perspektif Pendidikan Islam. Salatiga: IAIN Salatiga.

Sabilah, L., Darmalaksana, W., Nurdianawati, S., \& Tamami, T. (2021). 
Jurnal Riset Agama, Volume 1, Nomor 2 (Agustus 2021): 323-337

Muhammad Daffa/Solusi Pengolahan Sampah dalam Problem Pencemaran

Bumi untuk Kebersihan Lingkungan Hidup: Studi Syarah Hadis

Takhrij and Syarah Hadith of Agrotechnology: Study of Black Seed Content in Increasing Body Resistance During the Covid-19 Pandemic. Gunung Djati Conference Series, 139-146.

Shafwan, \& Hambal, M. (2020). Studi Ilmu Hadits: Panduan Lengkap memahami Ilmu Hadits Dirayah dan Riwayah serta Dilengkapi Studi Sembilan Kitab Induk Hadits. Malang: CV. Pustaka Learning Center.

Simanjuntak, A. (2019). Korelasi Budaya Malu pada Kebiasaan Masyarakat. Medan: Fakultas Ilmu Budaya Universitas Sumatera Utara.

Thobroni, A. Y. (2015). Internalisasi Nilai-nilai Kesadaran Lingkungan melalui Pendidikan Perspektif Al-Quran-Hadis. Prosiding Halaqah Nasional dan Seminar Internasional Pendidikan Islam (pp. 92-104). Surabaya: Universitas Islam Negeri Sunan Ampel Surabaya.

Wijaya, R. A. (2015). Implementasi Konsep Kebersihan sebagian dari Iman di IAIN Raden Fatah Palembang. Tadrib: Jurnal Pendidikan Agama Islam, 171-186. 